\title{
Filosofi Astha Brata dalam Kepemimpinan Wakil Rakyat Menuju Indonesia Konstitusional dan Berkedaulatan Rakyat
}

\author{
Andina Elok Puri Maharani \\ Universitas Sebelas Maret \\ andinaelok@staff.uns.ac.id
}

\section{Article History}

received $1 / 9 / 2021$

\begin{abstract}
This paper examines the leadership of the people's representatives towards a constitutional Indonesia and people's sovereignty in the perspective of the Astha Brata Philosophy. The issue in this paper is the crisis of leadership and public distrust of the performance of the people's representatives, in the context of this paper the members of the House of Representatives of the Republic of Indonesia. This crisis of confidence will gradually weaken democracy which is believed to be the way to prosperity based on people's sovereignty. The problems raised in this paper are why there are problems in the leadership of the people's representatives and how the Astha Brata philosophy is the answer in the leadership of the people's representatives towards a prosperous Indonesia with people's sovereignty. This type of research is doctrinal with a statutory approach, namely the 1945 Constitution of the Republic of Indonesia, legislation on elections and political recruitment, case approach and philosophical approach. The results of the study show that first, the root of the problem of the leadership of the people's representatives, namely an unhealthy political recruitment process, political education and regeneration that is not going well. Second, Astha Brata as a perfect philosophy to form leaders who have strong characters and provide protection towards a constitutional Indonesia and people's sovereignty.
\end{abstract}

Keywords: Astha Brata, Philosophy, Leadership, Deputy, Constitutional, People's Sovereignty

\begin{abstract}
Abstrak
Tulisan ini mengkaji soal kepemimpinan wakil rakyat menuju Indonesia konstitusional dan berkedaulatan rakyat dalam perspektif Filosofi Astha Brata. Isu dalam tulisan ini adalah krisis kepemimpinan dan ketidak percayaan publik terhadap kinerja wakil rakyat, dalam konteks tulisan ini yakni anggota Dewan Perwakilan Rakyat Republik Indonesia. Krisis kepercayaan ini lambat laun akan melemahkan demokrasi yang dipercayai sebagai jalan menuju kesejahteraan berdasarkan kedaulatan rakyat. Permasalahan yang diangkat dalam tulisan ini yakni mengapa terjadi permasalahan dalam kepemimpinan wakil rakyat dan bagaimana filosofi astha brata sebagai jawaban dalam kepemimpinan wakil rakyat menuju Indonesia sejahtera berkedaulatan rakyat. Jenis penelitian ini adalah doktrinal dengan pendekatan perundang-undangan yakni UUD NRI Tahun 1945, Peraturan perundang-undangan tentang pemilu dan rekrutmen politik, Pendekatan kasus dan pendekatan filofosi. Hasil penelitian menunjukkan pertama, akar masalah kepemimpinan wakil rakyat yakni proses rekrutmen politik yang tidak sehat, Pendidikan politik dan kaderisasi yang tidak berjalan baik. Kedua, Astha Brata sebagai filosofi sempurna untuk membentuk pemimpin yang memiliki karakter kuat dan memberikan pengayoman menuju Indonesia konstitusional dan berkedaulatan rakyat.

Kata kunci: Astha Brata, Filofosi, Kepemimpinan, Wakil, Konstitusional, Kedaulatan Rakyat
\end{abstract}

Social, Humanities, and Education Studies (SHEs): Conference Series https://jurnal.uns.ac.id/shes

p-ISSN 2620-9284

e-ISSN 2620-9292 


\section{PENDAHULUAN}

Parlemen atau lembaga perwakilan rakyat dengan berbagai nama di negaranegara di dunia merupakan salah satu pilar demokrasi.(Azed, 2014) Indonesia sebagai pemegang paham kedaulatan rakyat menjadikan wakil rakyat sebagai pemimpin rakyat. Parlemen menjadi wakil rakyat yang menampung aspirasi dan kepentingan rakyat sebagai pemegang kekuasaan tertinggi. Keberadaan wakil rakyat ini diharapkan mampu menjadi penyeimbang bagi kekuasaan eksekutif.

Hasil survey Politika Research and Consulting (PRC) dan Parameter Politik Indonesia (PPI) tahun 2021 menunjukkan sebanyak 50,5 persen responden menilai kinerja Dewan Perwakilan Rakyat (DPR) baik. Namun Lembaga Survey Fixpoll Research and Strategic Consilting pada 16-27 Juli 2021 menunjukkan hasil bahwa kinerja lembaga legislative mendapat tingkat kepuasan terendah dibandingkan Lembaga lain. Ketidak puasan tersebut disebabkan oleh kinerja penyusunan legislasi dan produk hukum yang dihasilkan dinilai tidak mencerminkan kehendak masyarakat. Bahkan DPR dianggap hanya sebagai mesin dari partai politik untuk kekuasaan sekelompok kecil. Kinerja wakil rakyat berdampak pada kepercayaan masyarakat. Menurunnya kepercayaan wakil rakyat ditunjukkan dengan kinerja wakil rakyat yang tidak sesuai dengan tingginya harapan masyarakat.

Sejatinya seorang wakil rakyat harus memiliki sifat kepemimpinan yang baik, dalam kajian filosofi sifat kepemimpinan yang baik ini digambarkan dengan astha brata. Apabila seorang wakil rakyat memiliki sifat ini maka ia akan mengetahui bagaimana tugas, pokok dan fungsinya sebagai corong dari kehendak rakyat. Rumusan masalah yang diangkat dalam tulisan ini yakni mengapa terjadi permasalahan dalam kepemimpinan wakil rakyat dan bagaimana filosofi astha brata sebagai jawaban dalam kepemimpinan wakil rakyat menuju Indonesia sejahtera berkedaulatan rakyat.

\section{A. Filosofi Astha Brata}

\section{KAJIAN TEORI}

Asta Brata berasal dari kitab Hindu dalam bahasa Sansekerta, Manawa Dharma Sastra. Asta sendiri artinya delapan dan Brata artinya tindakan pengendalian diri atau perilaku. Filosofi kepemimpinan ini merupakan contoh kepemimpinan hindu yang terdapat dalam Itihasa Ramayana. Asta Brata adalah delapan unsur kepemimpinan yang menjadi suatu ajaran, nasihat atau petunjuk yang diberikan oleh Sri Rama kepada sang Wibisana pada waktu penobatannya menjadi Raja di Negeri Alengka Pura. Begitupun wejangan Sri Rama kepada Bharata.

Dari ajaran Asta Brata, dalam menjadi seorang pemimpin yang baik haruslah selalu memiliki wiweka atau sikap berhati-hati terhadap segala tingkah lakunya dan terhadap keputusan yang diambilnya karena rakyat akan mengikuti segala tindakan yang dilakukan oleh pemimpin. Sehingga, perbuatan pemimpin cerminan perilaku rakyatnya. Dalam menyeimbangkan sistem kepemimpinan, seorang pemimpin haruslah memiliki acuan segala tindakan untuk mewujudkan kemakmuran dan kesejahteraan yang dipimpinnya.

Kedelapan ajaran Asta bhrata mengandung berbagai ajaran yang sangat berpengaruh dan menentukan berhasil tidak jalannya suatu pemerintahan. Adapun ajaran Asta Bhrata terdapat pada bagian-bagiannya adalah sebagai berikut. (Sudarmiati N 2020)

1. Indra Brata. Bahwa seorang pemimpin hendaknya jangan lupa pada rakyat yang di pimpinnya.

2. Yama Brata. Dalam hubungan ini para pemimpin diharapkan menegakkan hukum secara benar dan adil, yang bersalah menurut hukum, harus dihukum dan yang tidak bersalah harus dilindungi. 
3. Surya Brata. Para pemimpin hendaknya mampu memberikan penerangan secara benar, adil dan merata kepada seluruh warga negaranya.

4. Candra Brata. Para pemimpin hendaknya selalu dapat memperlihatkan wajah yang tenang dan berseri-seri dalam tugasnya sehari-hari, sehingga dengan demikian rakyat yang dipimpinnya merasa yakin akan kebesaran jiwa pemimpinnya serta simpati dan penuh rasa hormat.

5. Bayu Brata. Para pemimpin hendaknya selalu mengetahui keadaan dan kemauan rakyat yang paling bawah dan menderita.

6. Kuwera Brata. Para pemimpin hendaknya memiliki sifat-sifat bijaksana dalam mempergunakan dana, sehingga pembangunan masyarakat yang adil dan makmur dapat terwujud sebagaimana mestinya.

7. Baruna Brata. Para pemimpin hendaknya memiliki wawasan yang luas, dan sanggup mengatasi setiap gejolak dengan penuh kearifan.

8. Agni Brata. Para pemimpin hendaknya pemimpin memiliki semangat yang berkobar-kobar seperti api dan tidak pernah putus asa dalam menyelesaikan semua perkara yang terjadi dalam kepemimpinannya.

Ajaran Asta Brata pada prinsipnya adalah proses dewataisasi yaitu menjadikan seorang pemimpin memiliki sifat-sifat kedewaan sehingga rakyat yang dipimpinnya menjadi sejahtera dan bahagia. Konsep kepemimpinan Asta Brata merupakan filosofi kepemimpinan hindu dimana seorang pemimpin diibaratkan mempunyai kekuatan delapan Dewa yang merupakan manifestasi dari Tuhan yang bersemayam pada dirinya. Ajaran ini tentunya menuntun seorang pemimpin untuk menuju keharmonisan bagi masyarakat atau organisasi yang dipimpinnya.(Aryawan 2021).

\section{B. Teori Rekrutmen Politik}

Dilihat dari sisi etimologi, kata politik berasal dari bahasa Yunani, yakni polis yang berarti kota yang berstatus negara kota (city state). Secara umum, politik pada hakikatnya the art and science of government atau seni dan ilmu pemerintahan. Definisi politik dalam wacana teoritis sangatlah beragam. Dalam sistem politik demokrasi, rekrutmen politik menjadi khas dalam menjalankan partai politik. Rekrutmen politik secara demokratis mempunyai makna yaitu berlandaskan pada nilainilai dan prinsip demokrasi yaitu kebebasan, kesamaan atau keadilan dan kedaulatan suara mayoritas. (Anggraini 2019). Fungsi rekrutmen adalah kelanjutan dari fungsi mempertahankan dan mencari kekuasaan. Rekrutmen berkaitan dengan sejauh mana partai politik melakukan seleksi, kandidasi, dan menyiapkan kader-kader politik untuk memimpin negara dan pemerintahan yang bersih, anti korupsi, berintegritas, akuntabel, dan dapat dipercaya. (Anggoro 2020) Adapun yang dimaksud dengan rekrutmen politik adalah proses oleh partai politik dalam mencari anggota baru dan mengajak orang berbakat untuk berpartisipasi dalam proses politik. (Fitriyah 2020) Adanya rekrutmen dalam partai politik dapat dijadikan sebagai tolak ukur dari keberhasilan partai dalam memilih kader terbaiknya, yang nantinya juga akan menjadi penentu wajah partai di ruang publik. (Anshari dan Fadiyah 2019)

Konstitusi mengatur rekrutmen politik sebagai ranah partai politik. empat hal penting dalam rekrutmen politik oleh partai politik, yakni (1) siapa yang dapat dinominasikan sebagai calon; (2) siapa yang melakukan seleksi calon (selectorate) ; (3) dimana calon diseleksi; dan (4) bagaimana calon diputuskan. (Hazan \& Rahat, 2006: 110-114) Berdasar pada empat hal tersebut dihasilkan model pengelolaan rekrutmen partai yang dilakukan apakah inklusif atau eksklusif, dan apakah sentralistik atau desentralistik. Rekrutmen politik akan menjamin kontinuitas dan kelestarian partai. (Adelia 2020)

Menurut Firmanzah (Firmanzah 2011) mengemukakan bahwa partai politik harus melaksanakan fungsi rekrutmen politik: "Rekrutmen politik merupakan cara melakukan seleksi terhadap orang- orang yang akan menjadi pengurus partai politik harus diubah 
dan lebih berorientasi pada masalah bangsa dan negara. Selain itu, proses pengkaderan dan muatan-muatan politis yang diberikan kepada mereka harus diubah. Rekrutmen politik memegang peranan penting dalam sistem politik suatu Negara, karena proses ini menentukan orang-orang yang akan menjalankan fungsi-fungsi sistem politik negara itu melalui suprastruktur dan infrastruktur politik (Nendissa dan Rahakbauw 2020).

Setiap sistem politik memiliki tata cara atau prosedur rekrutmen yang berbedabeda. Rekrutmen politik menjadi suatu hal yang penting bagi pelaksanaan pemerintahan dan dalam pelaksanaaanya pun harus sesuai dengan kaidah yang berlaku agar terwujudnya sistem demokrasi yang sehat dan jauh dari unsur-unsur pencapaian tujuan politik yang kotor. Hal ini dilakukan guna untuk regenerasi penerus dalam suatu partai politik. Hal ini sangat penting karena tanpa seseorang yang mampu melaksanakan peranannya, kelangsungan hidup sistem politik akan memburuk.

\section{Prinsip Kedaulatan Rakyat}

Indonesia merupakan negara majemuk, kemajemukan masyarakat merupakan sesuatu yang bersifat given dalam struktur masyarakat Indonesia. (Rahma dkk 2021) Dari kemajemukan tersebut konsep kedaulatan rakyat dianggap sebagai konsep ideal. Kedaulatan rakyat menggambarkan suatu sistem dalam sebuah negara yang menghendaki kekuasaan tertinggi dipegang oleh rakyat. (Bachmid 2021) Kedaulatan rakyat memiliki beberapa prinsip yang berikatan satu sama lain. Prinsip-prinsip tersebut tercantum dalam Undang-Undang Dasar 1945 yaitu antara lain :

1. Prinsip Esensial

Prinsip esensial mengandung kebebasan dalam batas-batas konstitusional dan hukum. Sebagai pemegang kekuasaan tertinggi, rakyat bebas dari ancaman yang merugikan hidupnya. Tidak hanya itu, warga negara juga dibebaskan untuk melakukan sesuatu dalam hidupnya. Dengan diatur dan dijaminnya kebebasan dalam konstitusi negara, maka rakyat sebagai pemegang kedaulatan bebas berbuat apa saja untuk kebaikan hidupnya dalam bingkai konstitusi dan hukum. (Fahmi, 2010) Prinsip esensial tidak hanya mengandung kebebasan saja, tetapi juga persamaan. Aspek persamaan memiliki arti bahwa setiap warga memiliki hak untuk mendapatkan perlakuan sama di hadapan hukum.

2. Prinsip Prosedural

Prinsip prosedural mengandung aspek suara mayoritas dan pertanggungjawaban. Aspek suara mayoritas merupakan akibat dari adanya kebebasan dan persamaan. Aspek suara mayoritas melibatkan rakyat sebagai pemegang kekuasaan tertinggi secara luas dan langsung. Dapat dilihat dalam pemilu yang memerlukan suara mayoritas untuk menentukan seorang kepala negara. Selain aspek suara mayoritas terdapat aspek pertanggungjawaban. Dalam aspek pertanggungjawaban ini, rakyat memberikan kekuasaan penuh kepada para penyelenggara negara untuk menjalankan pemerintahan. Setiap penyelenggara negara mempunyai tanggung jawab masing masing dan wajib mempertanggungjawabkan tugas yang dipikulnya.

\section{METODE}

Jenis penelitian ini adalah doktrinal dengan pendekatan perundang-undangan yakni UUD NRI Tahun 1945, Peraturan perundang-undangan tentang pemilu dan rekrutmen politik. Pendekatan yang digunakan dalam penelitian ini adalah pendekatan kasus dan pendekatan filofosi. Sumber data dilakukan dengan studi kepustakaan, yaitu dengan membaca dan menelaah buku-buku literatur dan jurnal tentang Astha Brata, Filofosi, Kepemimpinan, Wakil Rakyat, dan Kedaulatan Rakyat.

Teknis analisis data yang digunakan menyesuaikan dengan rumusan masalah. Rumusan masalah pertama tentang mengapa terjadi permasalahan dalam 
kepemimpinan wakil rakyat akan dijawab dengan pisau analisis yakni teori rekrutmen politik, dan peraturan perundang-undangan. Sedangkan rumusan masalah kedua yakni bagaimana filosofi astha brata sebagai jawaban dalam kepemimpinan wakil rakyat menuju Indonesia konstitusional dan berkedaulatan rakyat akan dijawab dengan mengkaji filosofi astha brata..

\section{HASIL DAN PEMBAHASAN}

\section{A. Penyebab Terjadinya Permasalahan Dalam Kepemimpinan Wakil Rakyat}

Pemilu merupakan pintu pertama untuk mencari wakil rakyat yang berkualitas. Setiap negara menyelenggarakan pemilu terlepas dari apakah ia merupakan negara demokratis. (Husnul Isa Harahap 2021). Rekrutmen politik merupakan tahap awal bagi partai politik sebelum mengikuti pemilu. Terdapat persoalan besar dalam proses rekrutmen politik dan seleksi para kandidat untuk menjadi elite politik. Ketidakberhasilan elite menjalankan amanah masyarakat sebagai wakil rakyat bisa dilihat dari awal rekrutmen politik dan seleksi kandidat yang diselenggarakan. Setiap wakil tentulah dituntut mempunyai kemampuan atau keahlian yang diperkirakan atau diharapkan dapat menjalankan tugas perwakilkan. (Rahman dan Prayuda 2020) Saat ini, integritas moral dan kompetensi politik calon wakil rakyat dalam pemilihan wakil rakyat cenderung diabaikan. Justru yang dijadikan pertimbangan adalah popularitas untuk menaikkan perolehan suara dan yang memiliki uang dapat membantu partai politik melaksanakan aktivitasnya pada pemilu.

Desain regulasi memberikan ruang dominan kepada elite partai menentukan siapa yang dipilihnya untuk dicalonkan sebagai anggota DPR. Pada titik akhirnya, obyektifitas dalam mekanisme rekrutmen menjadi satu-satunya harapan terwujudnya rekrutmen ideal. Permasalahan terhadap kepemimpinan wakil rakyat salah satunya terjadi akibat ketidak stabilan kehidupan politik dan kemasyarakatan yang tidak ditandai dengan upaya memberdayakan pendidikan politik rakyat. Lemahnya regulasi pendidikan politik memberi cerminan kurangnya komitmen terhadap pentingnya pendidikan politik. Pendidikan politik memberikan pengetahuan kepada rakyat dan kader terhadap proses demokrasi dalam negara hukum.

Permasalahan yang lain adalah ketika adanya pemilihan secara aklamasi di dalam tubuh partai politik dalam memilih kepemimpinan untuk menjadi wakil rakyat. Biasanya yang terjadi adalah adanya kandidat seorang figur tertentu dalam pemegang amanat. Adanya figuritas tunggal atau monopoli figur dalam suatu partai politik kecenderungan disebabkan karena miskinnya kaderasi (pendidikan politik atau vooter education) yang dilakukan, sehingga tidak muncul figur tokoh alternatif tempat di mana konstituen dapat membanding-bandingkan kualitas (mutu) kepemimpinan. (Kurniawan, 2010)

Implikasi nyata dalam tata ruang yang kurang demokrasi bisa dilihat dari beberapa partai politik dalam mencari pengurus dan kader-kadernya. Seperti yang dicermati saat ini dalam media elektronik maupun media cetak yang lainnya, masih terdapat banyak pengurus dan kader partai politik yang belum memahami pendidikan politik yang diberikan partai terhadap peningkatan wawasan kebangsaan bila mana setiap pengurus berbicara soal nilai-nilai kebangsaan maupun nilai yang tercamtum dalam AD/ART partai. (Nasution 2012)

Mayoritas partai politik saat ini belum mampu secara murni dalam menjalankan pola rekrutmen dan mekanisme kaderisasi sesuai aturan karena partai politik dipengaruhi oleh politik kekerabatan dan mekanisme kaderisasi instan dari orangorang yang memiliki popularitas. Performa partai politik yang semakin krusial menyebabkan melemahnya peran dan fungsi organisasi atau lembaga negara. Dapat dibayangkan jika partai politik sebagai sumber pemimpin nasional tidak memiliki pola rekrutmen dan mekanisme kaderisasi yang baik, tentu ini akan memunculkan berbagai persoalan, yang salah satunya ditunjukkan dengan adanya politik kekerabatan. 
Bertumbuh kembangnya politik kekerabatan, memunculkan sejumlah ketimpangan karena politik kekerabatan menutup akses bagi orang-orang yang memiliki sumberdaya yang terbatas dan tidak memiliki hubungan kekerabatan untuk dapat menjabat di posisi-posisi politik. Sedangkan bagi mereka yang memiliki jaringan yang kuat, sudah dipastikan dapat diakumulasi pengaruh, kekayaan dan juga penguasaan wilayah. Jika suatu wilayah telah dikuasai oleh sekelompok elit bahkan dari keluarga yang sama, maka sumberdaya daerah tersebut akan dikuasai oleh mereka. Dapat dipastikan bahwa kekuatan utama berada pada segelintir elit sehingga jalan kepentingannya pun tidak menutup kemungkinan hanyalah untuk kepentingan para elit, bukan untuk kebaikan bersama. Melihat berbagai permasalahan yang ada, peran partai politik sudah seyogyanya lebih ditekankan untuk memaksimalkan fungsi partai politik dalam membangun demokrasi melalui pendidikan politik dan pengkaderan.

\section{B. Filosofi Astha Brata Sebagai Jawaban Dalam Kepemimpinan Wakil Rakyat Menuju Indonesia Konstitusional dan Berkedaulatan Rakyat}

Astha Brata merupakan istilah dari Jawa yang berarti delapan aku atau delapan watak yang harus dimiliki manusia khususnya yang berkedudukan sebagai pemimpin. (Suhari 2014) Hasta Brata dipercaya sebagai sebuah ajaran kode etik kepemimpinan dari zaman dahulu hingga sekarang yang populer di kalangan masyarakat Jawa. (Kurniawan 2019) Watak yang harus dimiliki oleh seorang pemimpin sesuai dengan ajaran astha brata yaitu :

1. Bumi (Laku Hambeging Kisma)

Bumi diartikan sebagai tetap yang artinya seorang pemimpin harus memiliki pendirian teguh atau konsisten dalam mengambil keputusan. Bumi juga diartikan sebagai keadilan bagi seluruh rakyatnya. Artinya adalah seorang pemimpin tidak membeda-bedakan antara rakyat satu dengan yang rakyat lainnya.

2. Matahari (Laku Hambeging Baskara)

Matahari selalu memberi penerangan, kehangatan, serta energi yang merata di seluruh pelosok bumi.(Sundari 2014) Seorang pemimpin harus mampu memberikan motivasi dan memberikan ilmunya bagi orang yang dipimpin.

3. Bulan (Laku Hambeging Candra)

Menjadi seorang pemimpin harus mampu menjadi penerang dikala gelap yang artinya pemimpin harus mampu mencari jalan keluar ketika terjadi sebuah permasalahan.

4. Bintang (Laku Hambeging Kartika)

Penunjuk arah disimbolkan oleh bintang. Menjadi pemimpin diharapkan dapat menjadi suri tauladan yang mampu memberikan arahan bagi para anggotanya.

5. Api (Laku Hambeging Dahana)

Api memiliki sifat panas dan membakar. Dalam satu kelompok terdapat ancaman yang mampu memecahbelah kelompok tersebut. Sifat Api yang dimiliki pemimpin diharapkan mampu menghancurkan ancaman tersebut.

6. Angin (Laku Hambeging Samirana)

Seorang pemimpin haruslah memiliki sifat Laku Hambeging Samirana. Pemimpin yang baik adalah pemimpin yang mampu menempatkan dirinya dimana saja, kapan saja, dan dalam situasi apapun. Pemimpin yang memiliki sifat angin tidak akan mudah digoyahkan oleh orang lain.

7. Laut atau Samudra (Laku Hambeging Samodra)

Laut digambarkan sebagai wujud alam yang tenang, sejuk dan menyegarkan. Pemimpin harus memiliki sifat laut, yang artinya pemimpin harus mempunyai sifat pemaaf dan siap menampung segala hal yang menjadi problematika anggotanya.

8. Air (Laku Hambeging Tirta) 
Sifat air dalam pemimpin diartikan sebagai sifat yang adil dan menjunjung derajat anggotanya. Seorang pemimpin harus mampu menempatkan diri sesuai wadahnya sama seperti air.

Konsep astha brata ini memiliki keterkaitan erat dengan Pancasila dan konstitusi. Undang-Undang Dasar Negara Republik Indonesia Tahun 1945 Pasal 1 Ayat (2) berbunyi "Kedaulatan berada di tangan rakyat dan dilaksanakan menurut UndangUndang Dasar". Indonesia menganut paham kedaulatan rakyat yang mana tercantum dalam konstitusi Indonesia yaitu UUD NRI Tahun 1945 dalam kekuasaan yang sesungguhnya berasal dari rakyat, oleh rakyat dan untuk rakyat dalam penyelenggaraan kekuasaan ini dilakukan bersama-sama langsung dengan rakyat sesuai dengan prosedur konstitusi indonesia, sedangkan indonesia sendiri juga menganut paham kedaulatan hukum yang dalam pelaksaannya dilakukan secara bersama-sama dengan kedaulatan rakyat. (Qoroni dan Winarwati 2021) Rakyat sebagai pemegang tahta tertinggi memberikan mandat kepada para wakil rakyat sebagai pemimpin untuk melaksanakan perananannya dalam menjalankan pemerintahan. Sebagai seorang rakyat, pasti akan berharap memiliki pemimpin yang mampu membawa negara di titik teratas. Tidak hanya itu, harapan rakyat sangat besar terhadap seorang pemimpin. Rakyat pastinya berharap bahwa wakil rakyat yang akan memimpin mereka memiliki jiwa tanggung jawab yang besar. Seorang pemimpin diajarkan untuk memiliki etika dan moral yang baik dengan menunjukkan sikap-sikap yang bijaksana dalam hal penggunaan dana atau uang, serta selalu adanya suatu keinginan untuk mensejahterakan masyarakat sehingga tidak menjadi sosok pemimpin yang boros yang pada akhirnya dapat merugikan masyarakat. (Sastrawan 2019) Selain itu, pemimpin juga diharapkan mampu mengayomi dan menciptakan kehidupan yang harmoni. Harmoni dan kesemibangan kehidupan berkairan dengan kedamaian, kebahagiaan dan kesehatan fisik dan mental masyarakat. (W. Julian Korab-Karpowicz 2021)

Dalam peranannya sebagai seorang pemimpin, wakil rakyat diharapkan memiliki 8 sifat astha brata yang menunjukkan ciri pemimpin idaman. Apabila sifat kepemimpinan astah brata dimiliki oleh para wakil rakyat saat ini, maka tidak akan ada lagi krisis kepercayaan terhadap seorang pemimpin. Para pemimpin jaman sekarang kurang memaknai dan memahami sifat astha brata yang harus dimiliki oleh seorang wakil rakyat. Oleh karena itu, alangkah baiknya apabila para pemimpin mempelajari lebih dalam lagi mengenai sifat astha brata sehingga mampu membawa sebuah negara pada puncak keemasan. Selain itu, apabila seorang pemimpin memiliki sifat astha brata, maka ketenangan dan ketenteraman rakyat akan terwujud

\section{SIMPULAN}

1. Akar masalah kepemimpinan wakil rakyat yakni proses rekrutmen politik yang tidak sehat, Pendidikan politik dan kaderisasi yang tidak berjalan baik.

2. Astha Brata sebagai filosofi sempurna untuk membentuk pemimpin yang memiliki karakter kuat dan memberikan pengayoman menuju Indonesia konstitusional dan berkedaulatan rakyat. Watak yang harus dimiliki oleh seorang pemimpin sesuai dengan ajaran astha brata yaitu: a) Bumi (Laku Hambeging Kisma), b) Matahari (Laku Hambeging Baskara), c) Bulan (Laku Hambeging Candra), d) Bintang (Laku Hambeging Kartika), e) Api (Laku Hambeging Dahana), f) Angin (Laku Hambeging Samirana), g) Laut atau Samudra (Laku Hambeging Samodra), h) Air (Laku Hambeging Tirta). Astha brata ini berkaitan erat dengan Pancasila dan UndangUndang Dasar Negara Indonesia Tahun 1945. Ketika wakil rakyat sebagai corong dari kehendak rakyat memiliki 8 sifat kepemimpinan ini maka Indonesia akan menjadi negara yang konstitusional dan berkedaulatan rakyat.. 


\section{DAFTAR PUSTAKA}

Abdul Bari Azed. 2014. "Menyoroti Kinerja Legislasi DPR". Jurnal Legalitas, Edisi Juni Vol VI, No. 1.

Adlina Adelia. 2020. "Implikasi Sistemik Dari Rekrutmen Kepala Daerah Oleh Partai Politik". Journal of Islamic Law And Studies, Juni, Vol. 4 No. 1.

Ahmad Febri Kurniawan. 2019. "Falsafah Kepemimpinan Pendidikan (Hasta Brata Sebagai Basis Kepemimpinan Pendidikan)". Jurnal Ri'ayah, Juli-Desember Vol. 04, No. 02.

Asri Sundari. 2014. "Kearifan Lokal Dalam Institusi Publik: Studi Gaya Kepemimpinan Jawa Hastabrata Pada Sekolah Menengah Di Kabupaten Jember". Jurnal Literasi, Desember, Vol 4. No. 2.

Diah Anggraini. 2019. "Rekrutmen Kandidat Perempuan Oleh Partai Politik (Studi Kasus: Pilkada Kabupaten Muaro Jambi Tahun 2017)". Jdpl (Jurnal Demokrasi Dan Politik Lokal), April, Vol I Nomor 1.

Fahri Bachmid. 2021 "Eksistensi Kedaulatan Rakyat Dan Implementasi Parliamentary Threshold Dalam Sistem Pemilihan Umum Di Indonesia". Sign Jurnal Hukum. Maret Vol. 2, No. 2.

Fitriyah. Partai Politik, Rekrutmen Politik Dan Pembentukan Dinasti Politik Pada Pemilihan Kepala Daerah (Pilkada). Politika: Jurnal IImu Politik (11). Nomor 1. 2020.

Firmanzah. 2011. Mengelola Partai Politik, Komunikasi dan Positioning Ideologi Politik di Era Demokrasi. Jakarta : Yayasan Obor Indonesia

Hazan, R. Y., \& Rahat, G. 2006. Candidate Selection:Methods And Consequences. Dalam Richard S. Katz And William Crotty. Handbook of Party Politics. London: Sage Publications

Husnul Isa Harahap. Journal of Social and Political Science, Vol 4, Number 1, 2021

Ilham Anshari dan Dina Fadiyah. 2019. "Pola Rekrutmen Partai Politik (Studi Kasus: Dewan Pimpinan Cabang Partai Amanat Nasional Kota Bekasi Dalam Menetapkan Calon Anggota Legislatif DPR RI Tahun 2014-2019)". Jurnal Polinter Prodi Ilmu Politik Fisip Uta'45 Jakarta. September-Februari Vol. 4 No. 2

I Wayan Aryawan. 2021. "Penerapan Kepemimpinan Asta Brata Dalam Pendidikan Dari Sudut Pandang Teori Konflik". Jurnal IImiah IImu Sosial. Vol 7. No 1.

Ketut Bali Sastrawan. 2019 "Menggagas Kepemimpinan Berlandaskan Ajaran Asta Brata Dan Etos Kerja Terhadap Kinerja Guru". Purwadita: Jurnal Agama dan Budaya. September Vol. 3, No. 2.

Khairul Fahmi. 2010 "Prinsip Kedaulatan Rakyat Dalam Penentuan Sistem Pemilihan Umum Anggota Legislatif". Jurnal Konstitusi. Juni Vol 7. No 3.

Khairul Rahman dan Rendi Prayuda. 2020. "Pemilihan Umum Di Indonesia: Pemimpin Dan Wakil Rakyat Yang Ideal". Jurnal Kemuntin. Juli Vol 1 No 2.

Kurniawan. Jurnal, "Proses Pemilihan Ketua Partai Politik Yang Demokratis ", Fakultas Hukum Universitas Syiah Kuala (Unsyiah)-Aceh.

Korab, W. Julian-Karpowicz. Social Harmony or a Happy Society. International Journal of Philosophy. Vol 9 No 3.

Muhammad Arifin Nasution. 2012. "Peranan Parpol Dalam Pendidikan Politik Dan Wawasan Kebangsaan". Jurnal Politeia. Januari. Vol.4

Rahma Winny Indahsari. 2021. "Presidential System Government In Style of The 1945 Constitution Amandement". Journal of Politics and Policy. June, Vol 3, No 2,

Reny Heronia Nendissa Dan Claudio Patrick I Rahakbauw. 2020. "Transparansi Partai Politik Dalam Rekrutmen Calon Legislatif". Jurnal Sasi. Januari-Maret Vol 26 No 1.

Sudarmiati, N. 2020. "Landasan Ajaran Asta Brata Dalam Kepemimpinan Kepala Sekolah Di SMAN 7 Luwu Timur". Jurnal IImu Pendidikan. Vol 2. 
Suhari. 2014. "Nilai-Nilai Ajaran Hastabrata Dalam Laokon Pewayangan Makutharama Sebagai Media Membangun Karakter Bangsa". Jurnal Budaya Nusantara. Desember Vol.1. No.2.: 154-160.

Teguh Anggoro, Dkk. 2020. "Rekrutmen Politik Calon Kepala Daerah (Studi Tentang Seleksi Kandidat Pada Partai Amanat Nasional Pada Pemilukada Di Kota Tasikmalaya Tahun 2017)". Jurnal Tapis: Jurnal Teropong Aspirasi Politik Islam. Vol. 16, No. 1.

Waisol Qoroni Dan Indien Winarwati. 2021. "Kedaulatan Rakyat Dalam Konteks Demokrasi Di Indonesia”. Journal Inicio Legis, Juni Vol. 2 No. 1. 